\title{
BIOFILM AND TUMOR: INTERPRETATION OF INTERACTION AND TREATMENT STRATEGIES. Review
}

\author{
Ivanenko N. https://orcid.org/0000-0002-3440-1684 \\ Donetsk National Medical University, Kropyvnytskyi, Ukraine \\ natalimarkowskaj@gmail.com
}

Relevance. Treatment of solid tumors and biofilm-derived infections face a common problem: drugs often fail to reach and kill cancer cells and microbial pathogens because of local microenvironment heterogeneities. There are remarkable challenges for current and prospective anticancer and antibiofilm agents to target and maintain activity in the microenvironments where cancer cells and microbial pathogens survive and cause the onset of disease. Bacterial infections in cancer formation will increase the coming years. Collection of approaches such as ROS modulation in cells, tumor is promoted by microbe's inflammation can be a strategy to target cancer and bacteria. Besides that, bacteria may take the advantage of oxygen tension and permissive carbon sources, therefore the tumor microenvironment (TM) becomes a potential refuge for bacteria. It is noteworthy that the relation between cancer and bacteria is intertwined.

Objective: To analyze similarities biofilm and tumor milieu that are produced against stress conditions and heterogeneous microenvironment for combination of approaches the bacteriotherapy with chemotherapy which can help in defeating the tumor heterogeneity accompanied with malignancy, drug-resistance and metastasis.

Method: An analytical review of the literature on keywords from the scientometric databases PubMed, Wiley.

Results: Bacteria evade antimicrobial treatment is mainly due to persistence that have become dormant during stationary phase and tolerance. Drug-tolerant persisters and cellular dormancy are crucial in the development of cancer, especially in understanding the development of metastases as a late relapse. Biofilms are formed by groups of cells in different states, growing or non-growing and metabolically active or inactive in variable fractions, depending on maturity and on chemical gradients $\left(\mathrm{O}_{2}\right.$ and nutrients) of the biofilms producing physiological heterogeneity. Heterogeneity in the microenvironment of a cancer can be described as a non-cell autonomous driver of cancer cell diversity; in a highly diverse microenvironment, different cellular phenotypes may be selected for or against in different regions of the tumor. Hypoxia, oxidative stress and inflammation have been identified as positive regulators of metastatic potential, drug resistance and tumorigenic properties in cancer. It is proven that, Escherichia coli (E. coli) and life-threatening infectious pathogens such as Staphylococcus aureus (SA) and Mycobacterium tuberculosis (Mtb) are noticeably sensitive to alterations in the intracellular oxidative environment. An alternative emerging paradigm is that many cancers may be promoted by commensal microbiota, either by translocation and adherence of microbes to cancer cells or by the distant release of inflammation-activating microbial metabolites. Microbial factors such as F. nucleatum, B. fragilis and Enterobacteriaceae members may contribute to disease onset in patients with a hereditary form of colorectal cancer (CRC); familial adenomatous polyposis (FAP). These findings are linked with the creation of new biomarkers and therapy for identifying and treating biofilm- associated cancers. Currently, about $20 \%$ of neoplasms globally can be caused by infections, with approximately 1.2 million cases annually. Several antineoplastic drugs that exhibited activity against S. mutans, including tamoxifen, doxorubicin, and ponatinib, also possessed activity against other Gram-positive bacteria. Drug repurposing, also known as repositioning, has gained momentum, mostly due to its advantages over de novo drug discovery, including reduced risk to patients due to previously documented clinical trials, lower drug development costs, and faster benchtop-to-clinic transition. Although many bacteria are carcinogens and tumor promoters, some have shown great potential towards cancer therapy. Several species of bacteria have shown an impressive power to penetrate and colonize solid tumors, which has mainly led to neoplasm slower growth and tumor clearance. Different strains of Clostridia, Lactococcus, Bifidobacteria, Shigella, Vibrio, Listeria, Escherichia, and Salmonella have been evaluated against cancer in animal models.

Conclusion. Cancer is a multifactorial disease and the use of bacteria for cancer therapy as an immunostimulatory agent or as a vector for carrying the therapeutic cargo is a promising treatment method. Therefore, the world has turned to an alternative solution, which is the use of genetically engineered microorganisms; thus, the use of living bacteria targeting cancerous cells is the unique option to overcome these challenges. Bacterial therapies, whether used alone or combination with chemotherapy, give a positive effect to treat multiple conditions of cancer.

Keywords: biofilm, tumor, heterogeneity, biomarker, repositioning, bacteriotherapy.

Relevance. Recognition of the fact that bacterial biofilm may play a role in the pathogenesis of disease has led to an increased focus on identifying diseases that may be biofilm-related. In the majority of cases, this is based on observations of biofilm-like structures in biopsies, autopsies, and exudates of patients and /or research animals. Additionally or alternatively, the presence of biofilm is indicated by studies on bacterial phenotypes during infection, immune responses, and vaccination experiments. Furthermore, the presence of biofilm may contribute to development of cancer [1].

Much of the microbiological research during the last century has focused on the investigation of the planktonic lifestyle of microorganisms. The challenge now is to decipher the specific features of the under researched biofilm lifestyle, because its ubiquitous nature and its importance in the clinic. Biofilm communities appear to be more complex than planktonic cultures. Not only is the 
cell physiology different, but any biofilm is composed of cells with diverse physiology one extreme being represented by dormant, metabolically silent, and persister cells. The basic concept of deleterious biofilms as microbial colonization of the 'wrong type of bacteria at the wrong place', can be even more dramatically exemplified in the arising association between biofilms and the development of certain cancers [2].

\section{METHOD}

An analytical review of the literature on keywords from the scientometric databases PubMed, Wiley. Search depth 5 years from 2016 to 2020 .

\section{RESULTS AND DISCUSSION}

Deeply studied in bacteria, bacterial biofilms represent multicellular assemblies of bacteria in contact with a surface and shielded by the extracellular matrix (ECM). Microbial lifestyle in biofilms, either viral or bacterial, is opposed structurally and physiologically to an isolated lifestyle, in which viruses or bacteria freely float in their environment. Biofilm grows until it becomes a macroscopic "mushroom"-like structure. Such biofilms are not uniform and contain channels that are believed to be essential for providing nutrients to bacteria embedded deeper in biofilm layers. Indeed, bacteria are present in different physiological states (anaerobic, dormancy, etc.) depending on their location in the biofilm, and on the availability of substrates, oxygenation, $\mathrm{pH}$, or exposure to metabolites present in the biofilm. After biofilm maturation, isolated or aggregated bacteria can dissociate and end up in the bloodstream. This detachment stage allows colonization of other sites, leading to the appearance of "metastasis" of the infection. Bacterial release from the biofilm requires degradation of biofilm polymers by enzymes and surfactant molecules that reduce surface-bacterial interactions. Although the processes leading to the synthesis, stability, and regulation of bacterial biofilms have been widely studied, the kinetics and dynamics of ECM remodeling mechanisms leading to the formation of viral biofilm have not been investigated yet, but can be drawn from scarce literature data [3].

The lifetime of bacterial cells is subdivided into two different phases: unicellular (planktonic) and multicellular (biofilm or sessile cells).

Modification between the two phases assumes the transfer from planktonic cells to sessile cells to trigger biofilm formation and from sessile cells to separated cells to provide a return to the planktonic state [4].

Biofilm formation can be described in four stages: (i) the planktonic cells reversibly attach to a suitable surface; (ii) the cells begin proliferating and irreversibly adhere to the surface to form microcolonies; (iii) the cells grow and mature from microcolonies into clusters of multilayered cells and begin to synthesize extracellular polymeric sub- stances (EPSs) that comprise the matrix; and (iv) some of the cells within the biofilm detach and disperse as planktonic cells to form biofilms in other settings. The adoption and maintenance of a biofilm mode of growth by bacteria is regulated by quorum sensing (QS), which is a system of intercellular communication that involves signaling molecules to coordinate various bacterial behaviors (enable the bacteria to persist in the host cells and escape the host defense immune system) and processes according to the cell population density [5].

The extracellular milieu is a key feature that controls the function of tumor and bacterial cells alike. In tumors, the extracellular matrix (ECM) is commonly altered and disorganized, while creating local areas of hypoxia and acidic $\mathrm{pH}$ that influence tumor progression. Additionally, the matrix becomes fibrotic and denser as solid tumors progress, further limiting diffusion. Altogether, the dysfunctional matrix presents diffusive barriers and create microenvironmental heterogeneity that hinder drug distribution and efficacy after extravasation from circulation. Bacterial EPS matrix facilitates the creation of physical and chemical heterogeneities as well as oxygen gradients and localized $\mathrm{pH}$ microenvironments in biofilms, modulating the bacterial survival and virulence at sites of infection. This feature has many similarities to the tumor milieu, with gradients resulting from diffusional limitation as well as cellular oxygen consumption and metabolic byproducts. Within biofilms, the structural, physiological and chemical heterogeneity of matrix-delineated microenvironments also contributes to reduced access and increased resistance of the embedded microorganisms to antibiotics. Furthermore, degrading the matrix can facilitate the transport into the tumor or biofilm microenvironments.

Although seemingly disparate diseases, treatment of solid tumors and biofilm-derived infections face a common problem: drugs often fail to reach and kill cancer cells and microbial pathogens because of local microenvironment heterogeneities. Furthermore, traditional systemic and, to a lesser extent, topical therapies can be toxic or have broad-spectrum activity, resulting in significant damage to healthy tissue. Common off-target effects for cancer chemotherapy are low red blood cell, platelet, neutrophil and immune cell counts, while antimicrobials are associated with nephrotoxicity, ototoxicity and neuromuscular blockade. Toxic side effects result in suboptimal treatment regimens and the eventual failure of therapy. Biofilm treatments, such as high-dose antibiotic administration, also cause substantial collateral damage including loss of potentially protective, commensal species, proliferation of opportunistic pathogens or even unintended induction of virulence factors, often with little effect on target pathogens. Biofilms and cancer have many unique conceptual similarities that can be exploited to design novel and selective drug delivery approaches. Tissue heterogeneity and compartmentalization 
alters accessibility of chemotherapeutic agents, provides protection from exogenously introduced antibiotics and promotes drug resistance. Furthermore, altered immune responses are often found within tumor and biofilms microenvironments. Thus, there are remarkable challenges for current and prospective anticancer and antibiofilm agents to target and maintain activity in the microenvironments where cancer cells and microbial pathogens survive and cause the onset of disease [6].

Planktonic bacteria colonizing a niche form microcolonies after adhere to the surface and multiplying. The initial small aggregates of bacteria with the uniform type of organization can progress to larger and more complex aggregates called biofilms. These structures are categorized in vitro as matrix covered bacterial (and/or archaeal) populations adhesive to each other or to surfaces and interfaces.

Selfsecreted, hydrated matrix in vitro contains of extracellular polymeric substances (EPS), which typically contributes more than $90 \%$ of the mass of biofilms. The human mucosal-associated bacterial biofilms may also include host proteins, mucopolysaccharides, nucleic acids and even whole host cells. Biofilms appear to promote to more than $80 \%$ of human soft and hard tissue infections due to the biofilms are ubiquitous and can be adherent to biological and nonbiological surfaces ensuring for the exchange of nutrients with their environment. Nevertheless, there are limitations in the study of biofilms in vivo (on a human host) despite their prevalence. In particular, this is due to the ability of biofilm-forming bacteria to horizontal transfer genes in the appropriate favorable environment, including antimicrobial resistance genes, which makes the eradication of biofilm by host defenses or antibiotics less effective. This avoidance of anti-microbials is first mediated by the EPS, which serves as a protective barrier to the biofilm- embedded bacteria in a manner similar to how the mucus layer protects epithelia in the human body. It is believed that biofilms can have a stable growth environment. However, the structures of bacterial populations that may be active, dormant, or resistant to antimicrobial agents contribute to the development of more quickly matrix response in evading host defenses [7].

Some bacterial cells within biofilms survive treatment with antimicrobials that have a greater effect on planktonic cells. It is believed that the ability of bacteria to evade antimicrobial treatment is mainly due to persisters. However, 'resistance' and 'tolerance' are also relevant in this context. Resistance is an inherited ability of a microbial population to grow despite the presence of a high concentration of an antimicrobial, irrespective of the duration of the treatment, but depending on the concentration of the particular antimicrobial that is termed 'minimum inhibitory concentration'. Similarly, tolerance is the ability of a microbial population to survive a transient exposure to an antimicrobial, irrespective of antimicrobial concentration which may even exceed the minimum inhibitory concentration, but highly depending on the duration of killing, termed 'the minimum duration for killing'. Persistence is also the ability of the bacterial population to persist antimicrobial treatment; however, unlike resistance and tolerance, it is the attribute of only a subpopulation of a clonal microbial population. Resistance is usually caused by inherited mutations, while tolerance, like persistence, may be triggered by slow growth rate, external stress factors that include starvation as well, host-environment factors and the antimicrobial itself [8].

Another source of persister cells is those that have become dormant during stationary phase. Such cells are simply carried over to the new culture upon sub-culturing. The mechanisms driving subpopulations of cells to enter the persistent state are the subject of intense research and debate. The ability of biofilms to house tolerant and persister cells is proposed to underlie the difficulties encountered in eliminating biofilms during chronic infections [9].

Strikingly, drug-tolerant persisters are also present in cancer cell populations, where they are implicated in tumor recurrence. These phenotypically variable cells can be a significant source of resistance to therapy. The intriguing parallel between cancer and infections, two seemingly distinct types of disease, indicates that antipersister strategies may also help to improve the treatment outcome of cancer. One of examples is the inhibition of lipid hydroperoxidase GPX4, and supports the viability of persistence cells, which ultimately leads to the loss of drug resistance by cancer cells. Collaborations of microbiologists and clinicians aimed at understanding the behavior of various cell states in biofilms can lead to a reduction in the ineffectiveness of therapy for both infectious diseases and cancer [10].

The dormancy of cancer cells plays a leading role in the formation of metastases as a late relapse, when the microenvironment provides a certain degree of metastasis. However, it should be considered that dormant cells, which can also propagate in primary tumors in places of hypoxia, are quite resistant to traditional cancer treatments, which target actively proliferating cells. In breast cancer, inhibition of $\beta 1$ integrin induced dormancy in vitro and in vivo. The mouse breast cancer cell lines, D2.0R and D2A1, both grow exponentially in 2-D culture conditions, but D2.0R fails to grow in 3-D cultures and become dormant. This is compatible with the in vivo results that D2A1 forms lung metastasis within short periods, whereas D2.0R has a long latency. D2A1 cells proliferate in 3-D cultures by producing fibronectin and forming actin stress fibers through activation of $\beta 1$ integrin. Thus, the interaction between the extracellular matrix and cancer cells plays an important role in cellular dormancy [11].

The slow growing small-colony variant (SCV) subpopulation is another equally puzzling phenotype that complicates biofilm formation as well as treatment and 
diagnosis of biofilm-related disease. The contribution of SCVs to biofilm formation has been studied for a rather small number of bacterial pathogens despite the huge clinical significance of persistent infections evading detection and complicating treatment. In combination, these different phenotypes within microbial communities give rise to an extremely resilient community that can withstand many stressors and shield the resident bacteria from eradication [12].

A morphological change described as small colony variants (SCVs) has been linked to various biofilm associated infections, such as cystic fibrosis, osteomyelitis and device-related infections. Since its first description for Salmonella enterica serovar typhi (S. typhi) almost 100 years ago, SCVs have now been reported for a wide range of bacterial genera and species, including Staphylococci, Escherichia coli, Pseudomonas aeruginosa, Vibrio cholerae, Shigella spp., Lactobacillus acidophilus, and Neisseria gonorrhoeae. Currently, the connection between the SCV phenotype and persistent, recurrent infections has become a hot topic in clinical microbiology. Phenotypically, the size of SCVs is about one tenth of that in regular colonies, with slow growth, atypical colony morphology, and acquired biochemical properties. They are less sensitive to antibiotics compared to their wild-type species. Furthermore, even if biofilm-associated bacteria express lower virulence per time compared with planktonic bacteria, cumulative effects on host cells may be higher. In addition, aggregative nature of biofilm-forming bacteria may enhance virulence through increased adherence to host cells, even if the same amount and potency of virulence molecules are produced or released. Part of biofilm-associated virulence is also derived from surrounding extracellular polymeric substance (EPS), not bacterial cells themselves. When compared with helical forms, coccoid forms of Helicobacter pylori (Hp) from peptic ulcer patients were found to express higher levels of proteins that are involved in virulence and carcinogenesis, such as secretion system machinery proteins, $\mathrm{CagE}, \mathrm{CagV}$, and YidC and proinflammatory proteins, such as OipA and Hps. More relevant to biofilm-associated $\mathrm{Hp}$, is reported that Streptococcus mitis induced $\mathrm{Hp}$ conversion to coccoid cells in co-culture studies and their proteomic analysis revealed a metabolic crosstalk between these two bacteria, suggesting a probable impact on Hp-associated carcinogenesis [13].

Antimicrobial resistance and the antibiotic tolerance are ensured by the density and physiological differentiation of subpopulations in the bacterial biofilm, as well as by the presence of a matrix that restricts the diffusion of chemical and biological substances in the biomass. Cells in biofilms exhibit complex physiological differentiation of populations, which is expressed in various gene expression and metabolic diversity regardless of an identical set of genetic material. Indeed, these metabolic changes can be due to stochastic factors such as spontaneous mutation, which fundamentally changes the genetic material within a cell. The microenvironment of the biofilm and the physiology of microorganisms have a reciprocal influence on each other, which creates phenotypic diversity in the biofilm. The matrix promotes the emergence of new subpopulations with the densification of biomass. Various studies have focused on the understanding of these heterogeneous subpopulations of cells within a biofilm stratum, which are characterized by distinct genetic programs, spatial segregation, and differential antibiotic susceptibility [14].

The growth and division of non-motile cells tends to produce densely-packed assemblages. The tight packing of cells is the natural consequence of population growth against a visco-elastic extra-cellular environment, and can be further promoted by attractive cell-cell interactions. Common examples range from microbial communities, in the form of colonies or biofilms, to multi-cellular structures, such as developing tissues or tumors. The evolution of cell populations in a dense microenvironment has not yet been sufficiently studied. When studying yeast colonies, it was observed that cells in slow-growing populations exhibit correlated movements that suppress differential dislocation that affect selection. This allows such clones to retain life-saving mutations and have advantages in reproduction. Is suggested that, in crowded populations, cells cooperate with surrounding neighbors through inevitable mechanical interactions. This effect has to be considered when predicting evolutionary outcomes, such as the emergence of drug resistance or cancer evolution [15].

Heterogeneity is a fundamental property of biological systems that contributes to development, differentiation, immune-mediated responses, and many other cellular, tissue, organ, and organism functions as well as diseases and disease progression. Whether heterogeneity is inherent to a population of cells, induced by the microenvironment, or induced by compound or reagent treatment, analysis of phenotypically similar cell subpopulations, derived from the analysis of heterogeneity, is expected to: improve the accuracy of cellular measurements; better support the interpretation of the data; provide insights into the regulation of cellular networks; guide the computational modeling of the networks; guide the prioritization of compounds for development in drug discovery; optimize the development of diagnostics for precision medicine and further basic biological knowledge [16].

Physiological heterogeneity is characterised by differences in gene expression, metabolic activity and phenotype, including antimicrobial tolerance, of cells located in different geographical areas of a biofilm. Heterogeneity arises due to the gradient of oxygen and of other nutrients within the biofilm. The role of hypoxia in contributing to biofilm tolerance to antimicrobials is further supported by the fact that biofilms treated with a variety of antimicrobials under global anaerobic conditions were more 
tolerant than similarly treated aerobic controls. There are different hypotheses that could also help explain how hypoxia confers antibiotic tolerance in biofilms. For example, a study examining the effects of hypoxia on multidrug efflux gene expression in P. aeruginosa demonstrated that the MexEF-oprN efflux pump genes are upregulated in oxygenstarved planktonic cells and contribute to antibiotic resistance in these cells, and it is possible that MexEF-OprN could also be contributing to the antibiotic resistance of biofilm subpopulations in areas with low oxygen tension. Subpopulations in bioilms are, as a result, physiologically heterogeneous, which makes the study of bioilms challenging since many experimental procedures such as susceptibility testing and transcriptomic proiling assess the bioilm as a whole instead of distinct bioilm subpopulations [17].

However, many biological aspects of tumor heterogeneity remain unknown. The analysis of multiple biopsies from the same tumor can reveal the spatial composition and evolutionary trajectory of subclones. The clonal and subclonal composition of each tumor can be used to construct distance-based phylogenetic trees. Mutations present in all samples of a tumor are inferred to be acquired by early precursor cells that clonally expanded (clonal mutations), represented by truncal events on the evolutionary tree, and mutations present in only a subset of samples are inferred to be later events, acquired at some point during or after the initial clonal expansion (subclonal mutations). Underestimation of tumor heterogeneity may lead to a serious flaw in cancer diagnosis and treatment selection [18].

In particular, intra-tumor heterogeneity (ITH) is closely related to cancer progression, resistance to therapy, and recurrences. New approaches were considered for the methods of clinical studies were revised taking into account morphological, molecular and histological aspects associated with ITH. The clonal one is related to different types of genomic instability that also influence aggressiveness and treatment. The nonclonal one is functional, microenvironment related, or stochastic, notably single cell efficiency related. Clonal and microenvironment ITHs are closely connected and influence each other. All these types of ITH affect cancer progression and treatment efficacy and should be considered as a whole for any patient [19].

Multiregional sampling, the method to sample biopsies from multiple regions within a single tumor, is the most common investigational strategy to determine the extent of ITH. This strategy is based on the "clonal evolution model", which was first proposed by Nowell in 1976, and became the most accepted hypothesis to depict the process of ITH in addition to the "CSC model" (cancer stem cell model). In this theory, carcinogenesis is considered to be a stochastic process. Numerous random genetic alterations created by genomic instability and continuous stimulation of carcinogens results in the emergence of subclones. The subclones with a survival advantage in a spatiotemporally specific microenvironment will establish dominance, while the non-adaptive subclones will be eliminated. Upon the selective pressure of the tumor microenvironments (TME), the complex architecture of ITH is preserved and dynamically reorganized [20].

The microenvironment is closely associated with genetic instability leading to genetic heterogeneity and the emergence of clone-positive mutations, especially in the early stages of cancer. The leading paradigm in cancer evolution is that genetic instability results in genetic heterogeneity leading to a phenotypically diverse pool of cancer subclones upon which selection can act [21].

It is evident that interference in different cell clones at the phenotypic level in a synergistic and antagonistic way can promote tumor evolution. It has also been shown that nondominant minor subclones can drive tumor evolution by interacting with the microenvironment, and several phenotypic functional constraints could influence clonal evolution. The functional phenotypic events in tumors are strictly associated with the microenvironment. Immune-histochemical biomarkers have already shown a high phenotypic level of heterogeneity in several types of tumors, and this was recently confirmed by the introduction of immunotherapy biomarkers [22].

Heterogeneity in the microenvironment of a cancer can be described as a non-cell autonomous driver of cancer cell diversity; in a highly diverse microenvironment, different cellular phenotypes may be selected for or against in different regions of the tumor. Different phenotypes may be genetically determined (such as the case of VHL/HIF1 mutants in kidney cancer), or they may be a consequence of plasticity in cellular behaviors, and further-more there may be feedback between the tumor cells and their microenvironment that drives specialisation of tumor cells and the concomitant strengthening of microenvironmental gradients [23].

According to the data obtained, the dynamic tumor microenvironment determines the malignant properties of tumor cells. Hypoxia, oxidative stress and inflammation have been identified as positive regulators of metastatic potential, drug resistance and tumorigenic properties in cancer. One of the markers of hypoxia is the transcription factor- $1 \alpha$ (HIF-1 $\alpha$ ) responsible for the expression of more than 100 genes. Its stabilization is associated with aggressive manifestations of cancer such as drug resistance and metastasis, which leads to a poor prognosis. Cancer cells are able to switch metabolic pathways by showing dependence on aerobic reactions, which lead to enhanced production and an elevation of intracellular level of reactive oxygen species ROS. Simultaneously, ROS activate signaling pathways of oncogenesis, weakening the expression of antioxidant genes and creating an aggressive tumor environment. The tumor-suppressive mechanisms by resveratrol, such as overproduction of ROS and subsequent activation of 
ROS-related signaling pathways could be utilized to develop anti-cancer strategies [24].

Reactive oxygen species (ROS) are metabolic byproducts of aerobic respiration and are responsible for maintaining redox homeostasis in cells. Redox balance and oxidative stress are orchestrated by antioxidant enzymes, reduced thiols and NADP $(\mathrm{H})$ cofactors, which is critical for cancer cells survival and progression. It is proven that Escherichia coli (E. coli), Staphylococcus aureus (SA) and Mycobacterium tuberculosis (Mtb) are noticeably sensitive to alterations in the intracellular oxidative environment. Thus, the development of approaches that utilize molecular structures including enzymes that modify the level of antioxidants and intracellular ROS, should be aimed at changing the redox potential of the cellular environment. These therapeutic strategies can provoke the death of tumor and bacterial cells [25].

Inflammation predisposes to the development of cancer and promotes all stages of tumorigenesis. However, an alternative emerging paradigm is that many cancers may be promoted by commensal microbiota, either by translocation and adherence of microbes to cancer cells or by the distant release of inflammation-activating microbial metabolites. These microbes and microbial products can even travel with tumors to the site of metastasis and serve as a source of inflammation in metastasis. Perhaps the best example of commensal microbiota influencing tumor growth and progression comes from colon cancer. Events following intestinal transformation lead to the deterioration of intestinal barrier, because hyperproliferating cells fail to properly differentiate and form protective tight and adherence junctions and well-developed mucus layer, isolating immune compartment from bacteria. In human colorectal cancer (CRC), quite a few of bacteria have been suggested to be preferentially associated with adenomas and carcinomas, including subspecies of Escherichia coli, Bacteroides fragilis and Fusobacterium nucleatum. A common denominator for these bacteria is their presence in tightly adherent fraction of bacteria capable of direct interaction with the surface of the tumor, either because of special ligand-receptor mode of adhesion, ability to form biofilms and initiate the outgrowth of the consortia of invasive bacteria or ability to induce low grade inflammation disrupting the barrier. It is reasonable to expect that the tumor promoting action of microbes in any of microbe rich cancer sites will be in part mediated by the inflammation they modulate [26].

Evidence from recent years strongly suggests that the tumor microenvironment (TME) is an indispensable participant in the metastatic process. Tumor is described as an unhealed chronically inflamed wound. Chronic inflammation is often associated with tumor processes in contrast to acute inflammation, which maintains the constancy of the internal environment-homeostasis and regeneration of tissues.

Many factors can trigger inflammatory response in tumors, including infection, tissue damage, activation of oncogenes, and loss of tumor suppressors (TS). p53 mutations are documented in over $50 \%$ of human cancers. Loss of normal p53 function is frequently associated with an increased susceptibility to inflammation-driven cancers such as ulcerative colitis-associated colorectal cancer. A strong association of p53 mutation and NF- $\mathrm{KB}$ activity has been observed in patients with head and neck squamous cell carcinoma (HNSCC) [27].

One study demonstrated that E. coli species that produce the genotoxin colibactin, induce tumor growth (TGF- $\beta$ ) by increasing production of hepatocyte growth factor in human and mouse colon cancer models. Colibactin promotes tumourigenesis through the production of growth factors as a result of alterations in the sumoylation of $\mathrm{p} 53$ [28].

Changes to the microbiome have been associated with various inflammatory diseases, such as atopic dermatitis and psoriasis as well as chronic lung diseases (chronic obstructive pulmonary disease (COPD) and cystic fibrosis), which are associated with the state of the lung microbiome. Interestingly patients with COPD have an increased incidence of inflammatory bowel disease (IBD), another disease that is associated with dysbiosis. The microbiota has also been implicated in various cancers, including pancreatic, gastric, liver and colorectal, a recent review highlights the increased risk of developing pancreatic cancer associated with dysbiosis of mouth and gut microbiota. In general, there is increasing evidence that the dynamic changes within the microbiome due to environmental factors such as diet and xenobiotics can affect both immune and cancer cells, whereby certain microbiota compositions and functions may be beneficial for cancer prevention, while other components may promote cancer. In addition, these findings are expanding beyond organs that are proximal to the gut microbiota (e.g. colon), suggesting that systemic processes may be modulated by aspects of the microbiome, such as the example of COPD and IBD incidence [29].

Since many epidemiological studies reveal a link between bacterial infections and cancer incidence, and the number of bacterial mechanisms that can contribute to cellular transformation are most likely considerable larger than reported to date, we expect that the number of examples illustrating the role of bacterial infections in cancer formation will increase the coming years. It is also known that bacterial effectors from different species can act synergistically during host cell manipulation and then act in a symbiotic interspecies manner. These combined mechanisms can induce cell transformation and cancer in an even more complex manner and further contribute to the complexity of bacterial contributions to cancer [30].

Bacteria is regarded as tumor inhabitant due to the poor immune activity within tumors. Besides that, bacteria may take the advantage of oxygen tension and permissive carbon sources, therefore the tumor microenviron- 
ment (TM) becomes a potential refuge for bacteria. It is noteworthy that the relation between cancer and bacteria is intertwined. Bacteria could have anti-tumor effect, as they may deplete nutrients that are required for metabolism of tumor cells. For instance, Bifidobacteria and Salmonella can invade solid tumors resulting in either retardation of neoplasm growth, or complete clearance of tumor. Conversely, bacteria may play a role in carcinogenesis, for example chronic urinary tract infection (UTI) is significantly associated with increasing breast cancer (BC) risk. Furthermore, intratumor bacteria may act as cancer allies and support its development, for instance, acute bacterial infection increases metastasis to the lung and Helicobacter pylori has implicated in gastric cancer development. Understanding how could bacteria influence cancer cells may help to elucidate cancer progression and provide useful therapeutic targets for treatment and prevention of metastatic cancer. It was considered that E. coli stimulation implicated in increasing transcription levels of CD44. CD44 is a family of non-kinase transmembrane glycoproteins found on embryonic stem cells and on other cell types. Hyaluronic acid (HA) is the main ligand for CD44, which is a constituent of the extracellular matrix (ECM) and it is expressed by stromal and cancer cells. It illustrated that CD44 may serve as microorganisms binding site, so that E. coli could bind to HA adherent to CD44 on urothelial cells, which facilitates E. coli migration through epithelial cells [31].

Interestingly, when a biofilm is detected on a tumor, its flanking normal tissue is mostly also covered by biofilm, suggesting that it expands over long distances in the tumor environment. The underlying mechanisms for the preferential proximal presence of tumor-associated biofilms are still unclear. Once the tumor is formed the bacterial biofilms in concerted action with the exacerbated inflammation, enforces more mucus production within the tumor cells. This will however only occur when the underlying genetic alterations allow for sufficient differentiation of the tumor cells or mucin gene expression. Thus, in this scenario, bacterial biofilms first contribute to more tumor formation and in a second phase to a specific differentiation pattern. In a second scenario, biofilm formation is secondary to tumor initiation. In that case, the biofilms mainly contribute to tumor progression and possibly increasing mucus production, likely again in concerted action with inflammation [32].

A number of studies have demonstrated compositional alterations in the luminal or tissue-associated bacteria between healthy and colorectal cancer (CRC) patients. Among the various microorganisms contributing to the differences in bacterial composition, Enterobacteriaceae family members that carry the genotoxic pks gene island, enterotoxigenic Bacteroides fragilis (ETBF) with the B. fragilis toxin (bft) gene, and Fusobacterium nucleatum have often been reported. However, the potential interactions between biofilm structures and cancer have attracted less attention. Microbial factors may contribute to disease onset in patients with a hereditary form of CRC; familial adenomatous polyposis (FAP). B. fragilis and Enterobacteriaceae members have also been identified within mucosal biofilms of intestinal biopsies collected from patients with inflammatory bowel disease, suggesting intestinal inflammation also influences host susceptibility [33].

Investigation of microbial composition of feces and mucosal microbiota along with tumor-bearing double-knockout mice revealed the duplicated results the enlarged colonization of Escherichia-Shigella and Parabacteroides. The inflammation also contributed to the density of Akkermansia, Bacteroides, and Parabacteroides in the fecal samples. Lactobacilli, Lachnospiraceae, and Muribaculaceae showed limited growth. In summary, chronic inflammation aggravates colonic tumorigenesis under mismatch repair deficiency and is associated with a shift in microbiota composition. Specific bacterial strains in the intestinal tract can lead to hyperproliferation by WNT-pathway activation, to DNA damage by bacterial toxins and to inflammation in the adjacent mucosa by destruction of the mucus layer enabling bacterial-epithelial contacts. In humans, fecal samples from patients with a carcinoma are enriched in species belonging to the genus Bacteroides, Parabacteroides and Escherichia, besides others, compared to patients with adenomas and healthy controls. These bacterial taxa are also associated with inflammation and carcinogenesis in mouse model [34].

That F. nucleatum nucleic acids are present in colorectal cancer tissues has since been confirmed in several different studies using varied molecular approaches (16S ribosomal RNA (rRNA) gene amplicon sequencing, DNA sequencing (DNA-seq), RNA sequencing (RNAseq) and directed quantitative PCR (qPCR)) and with fluorescent in situ hybridization. Such imaging-based data of bowel tumours suggest that F. nucleatum is in intimate association with the colorectal crypts and is perhaps even intracellular. Further, and very importantly, that viable F. nucleatum is present in these tissues has been verified by isolating F. nucleatum strains directly from biopsy samples and from patient-derived xenografts passaged in mice. What remains less clear is the breadth of these pathways that can be influenced by cancer-associated microorganisms such as F. nucleatum that shapes the tumour microenvironment [35].

Bacterial transcriptome that associated bacterial biofilms have been implicated in colorectal cancer (CRC), but it is still unclear what genes these microbial communities express and how they influence the host. MicroRNAs regulate host gene expression and have been explored as potential biomarkers for CRC. The murine response to different microbial communities (derived from CRC patients or healthy people) was evaluated through RNA and microRNA sequencing. These findings may lead to the development of new biomarkers and ther- 
apeutics for identifying and treating biofilm-associated colorectal cancers (CRCs) [36].

Diagnostic tests designed to determine the presence of biomarkers are very useful not only for diagnosis, but also for assessing the patient's prognosis and for developing therapies aimed at combating the onset and progression of tumors. Some genotoxins produced by enteric pathogenic species such as Salmonella, Escherichia, and Campylobacter have a synergistic effect on carcinogenesis However, there are ongoing debates on the use of F. nucleatum as a reliable CRC biomarker. Not only the method for microbial detection is important in this context, but also the predictive accuracy of microbial biomarker(s) using larger population-scale studies that also take into account the differences due to ethnicity and geography [37].

Preliminary studies suggested a possible correlation of microbiota with Barrett's esophagus (BE) and esophageal adenocarcinoma (EAC), where the need for tools to ameliorate its poor prognosis is mandatory. Pilot study identifies a unique microbial structure and function profile for $\mathrm{BE}$ and $\mathrm{EAC}$, as well as for metaplastic and near-normal areas. Microbiological diagnostics may open up new opportunities in the advancement of therapeutic approaches that require detailed studies of the microbiota shift and that can be also serve as an additional source for determining the diagnosis. A previous report on reflux esophagitis and $\mathrm{BE}$ characterized distal esophagus microbiota into two types. Type I microbiome was correlated with normal esophagus and, mainly, contained Gram-positive bacteria, primarily Firmicutes, and especially Streptococcus. Type II microbiome, mainly associated with reflux esophagitis and BE, was predominated by Gram-negative anaerobes and microaerophiles (phyla Bacteroidetes, Proteobacteria, Fusobacteria, and Spirochaetes). Further studies established that the dominant taxon within the healthy esophagus is Streptococcus and that the EAC cascade is depicted by a shift towards a prevalence of Gram-negative species. While following analyses have not replicated these observations, others have included the increase enrichment of specific Gram-negative species such as Campylobacter and $\mathrm{Fu}-$ sobacterium in the EAC process. Data confirms the characteristics of normal microbiota at esophageal level, with Streptococcus representing the main component. Beside this, it portrays EAC as an extreme dysbiotic perturbation of metaplastic mucosa (BEM) microbiota, which is dominated by Gram-negative anaerobes. The enrichment of oral organisms is increasingly being shown across several types of tumor. The identification of the microbial communities associated with cancer is of crucial importance in order to find risk factors and to hypothetically guide surveillance protocols. Thus, if coupled, genetic and microbial markers may help to prevent EAC or detect it at earlier, treatable stages, reducing the need for repeated surveillance procedures on large number of patients who never progress to cancer, thus ameliorating the management of this debilitating disease [38].

Currently, around $20 \%$ of neoplasms worldwide can be attributed to infections, with approximately 1.2 million cases annually. The research in the microbiome field and mainly the role of bacteria in cancer pathogenesis is rapidly evolving, with more than 100 trillion bacteria already identified in the human body. Currently, there is substantial evidence pointing to the role of bacterial microbiota in cancer pathogenesis. In this regard, $\mathrm{H}$. Pylori was highly correlated with the development of gastric adenocarcinoma and MALT lymphoma. S. Typhi was also reported to have a major impact in gallbladder cancer, especially in patients with gallbladder stones. S. gallolytucis was linked to colorectal cancer. Therefore, currently bacterial eradication is highly recommended for cancer treatment and prevention, mainly in gastric cancer and MALT lymphoma, while cholecystectomy remains the ideal prevention modality of gallbladder cancer [39].

Group A Streptococcus (GAS) provides colonization through a collagen-like protein 1 (Scl1) that can bind to two forms of fibronectin type III (FnIII) - cellular and within tenascin-C. Selective interaction of the globular domain the streptococcal collagen-like protein 1 (Scl1) with different forms of fibronectin expedited adhesion and biofilm formation. Similarly, cellular fibronectin isoforms and tenascin- $\mathrm{C}$ are present in the tumor microenvironment. Consistent with this, FnIII repeats mediate GAS attachment to and enhancement of biofilm formation on matrices deposited by cancer-associated fibroblasts and osteosarcoma cells. Interestingly, the aforementioned extracellular matrix (ECM) proteins components are also constituents of tumor microenvironment and our initial experiments suggest $\mathrm{Scl} 1$ has the capacity for targeting solid tumors. These data collectively support the premise for utilization of the Scl1-FnIII interaction as a novel method of anti-neoplastic targeting in the tumor microenvironment [40].

Several antineoplastic drugs that exhibited activity against $\mathrm{S}$. mutans, including tamoxifen, doxorubicin, and ponatinib, also possessed activity against other Gram-positive bacteria, further validating the AK assay. Ponatinib is a tyrosine kinase inhibitor that has a mechanism of action similar to that of the well-known "rationally designed" drug imatinib (Gleevec), used in the treatment of chronic myeloid leukemia. To date, no known antimicrobial activity of ponatinib has been reported, though imatinib has been shown to accentuate the bactericidal activity of macrophages against Mycobacterium tuberculosis and to inhibit the phosphorylation of CagA, a Helicobacter pylori virulence factor. While the genome of S. mutans does not encode tyrosine kinases or proteins with significant homology to the Helicobacter CagA, it does encode several ABC transporters with significant homology to the human target for leukemia (ABCG2). Secondary assays revealed 
that ponatinib inhibited growth of S. mutans planktonic cultures and was able to inhibit biofilm formation, as well as induce $\mathrm{AK}$ release from preformed biofilms. The antibacterial activity of ponatinib against $\mathrm{S}$. mutans is a novel finding. The adenylate kinase (AK) assay was originally adapted as a highthroughput method to detect lysis of fungal cells. Since then, it has been optimized for use with bacteria in high-throughput screens of the ESKAPE (Enterococcus faecium, Staphylococcus aureus, Klebsiella pneumoniae, Acinetobacter baumannii, Pseudomonas aeruginosa, and Enterobacter species) pathogens, as well as M. tuberculosis. Drug repurposing, also known as repositioning, has gained momentum, mostly due to its advantages over de novo drug discovery, including reduced risk to patients due to previously documented clinical trials, lower drug development costs, and faster benchtop-to-clinic transition [41].

The prevention of bacterial biofilm formation is one of the major current challenges in microbiology. It was demonstrated different mechanisms of action for individual compounds, from induction of replicative stress to disbalance of cation homeostasis to inhibition of bacterial attachment to the surface. Study demonstrates the potential of drug repurposing for the prevention of bacterial biofilm formation and suggests that also for other bacteria, the activity spectrum of antibiofilm compounds is likely to be broad [42].

Although many bacteria are carcinogens and tumor promoters, some have shown great potential towards cancer therapy. Several species of bacteria have shown an impressive ability to invade and colonize solid tumors, which has often led to neoplasm growth retardation and tumor clearance. Different strains of Clostridia, Lactococcus, Bifidobacteria, Shigella, Vibrio, Listeria, Escherichia, and Salmonella have been evaluated against cancer in animal models. Obligate or facultative anaerobic bacteria find favorable niches within the hypoxic and necrotic regions of the tumor. The systemic administration of bacteria can lead to their entry in the tumor tissue, proliferation, and the formation of a necrotic region by reducing oxygen and the nutrient supply. Thus, it causes the tumor cells in the center of the solid tumor to die from starvation and suffocation. Additionally, the bacteria, along with several other mechanisms have the ability to fight cancer cells, the most important of which include: (i) enhancing human immunity, (ii) as a carrier for cancer therapeutic agents, (iii) releasing substances (iv) forming biofilms, and (v) invading and colonizing the solid tumor [43].

Bacteria can colonize and proliferate in tumor microenvironments (TMEs) at a tumor-to-normal tissue ratio exceeding 10,000; thus, quorum sensing (QS) can be used as a gene expression switch. One example of QS system regulation can be autoinducer, synthetic LuxI protein, and the transcription protein LuxR. The acylhomoserine lactone (AHL) produced by LuxI, which de- pends on bacterial density, activates LuxR and promotes transcription of its target genes. AHL concentration-dependent QS systems have been used successfully to highly express heterologous proteins in bacteria-colonizing tumors. The QS approach has been used to introduce a variety of gene circuits [44].

Once inside the tumor, the tumor-targeting Salmonella with this gene circuit underwent repeated cycles of population expansion and regression by autolysis in response to the density of bacterial cells. The lysis of the cells directly released the anticancer drug made by the bacteria. Thus, this gene circuit provided maximal release of the therapeutic payload through synchronized cell lysis and increased safety by maintaining the intratumoral bacterial population at a defined size, consequently minimizing the risk of a devastating systemic inflammatory response. This example illustrates the potential of gene networks to coordinate the behavior of bacteria at the population level in response to a particular environmental cue for an increased therapeutic index. Tumor-targeting bacteria have further been shown to drive the G0/G1 to $\mathrm{S} / \mathrm{G} 2 / \mathrm{M}$ cell cycle transition of tumor cells, making them more susceptible to chemotherapy. Conversely, therapies with small molecules targeting tumor vasculature can enlarge the hypoxic niche inside the solid tumor, consequently increasing bacterial colonization, which is particularly important for tumors without extensive hypoxia. In addition, intratumoral bacterial infection can modulate antitumor immune response both systemically and in the tumor microenvironment, making it attractive to combine live bacteria with other systemic immunotherapeutic approaches such as immune checkpoint blockade [45].

Biofilm can be exploited as potential anti-cancer agents due to its ability to deliver therapeutics and to curb the spread of metastatic tumors. Anti-cancer agents induced and promoted biofilm formation in Pseudomonas aeruginosa during cancer treatment with hydroxyurea and doxorubicin. To escape the drug attack, the bacteria growing on the cancer cells are triggered by an SOS response, which is an inducible DNA damage repair system. This leads to the development of various unique bacterial phenotypes that attack or penetrate the cancer cells. Also, DNA and many proteins are released by the bacteria which coat the cancer cells and halt the metastatic escape of the tumor.

Cancer is a multifactorial disease and the use of bacteria for cancer therapy as an immunostimulatory agent or as a vector for carrying the therapeutic cargo is a promising treatment method. Several clinical trials are underway to test the efficacy of bacterial therapy on human subjects. However, a major problem with bacteria mediated cancer therapy is the toxicity. The dose for obtaining therapeutic effect may be toxic and have deleterious effects whereas lower doses can affect the treatment efficacy. The balance between the benefit and safety of the trial subject must be maintained. Appropri- 
ate techniques and measures must be adopted to evaluate the immune response of the subject and the overall therapeutic benefit. Differences in tumor structure between preclinical animal models and the human subjects can impact bacterial penetration and proliferation in the tumor. Hence, optimization of the dose and route of administration is critical. Moreover, bacterial clearance by the immune system before reaching the tumor site may result in the failure of treatment. Also, any mutations in the bacteria may result in the therapeutic loss and cause exaggerated infections. However, the use of recombinant DNA technology has mostly solved the safety concerns [46]. Therefore, the world has turned to an alternative solution, which is the use of genetically engineered microorganisms; thus, the use of living bacteria targeting cancerous cells is the unique option to overcome these challenges. Bacterial therapies, whether used alone or combination with chemotherapy, give a positive effect to treat multiple conditions of cancer. Also, bacteria can be used as vectors for drug, gene, or therapy, and this is a great step to treat cancer. There are several unique mechanisms by which bacteria can colonize a tumor, compete for oxygen and nutrient sources, significantly diminish angiogenesis, and ultimately reduce the proliferation of tumor cells. To this end, an attenuated wild strains of Salmonella typhimurium with a ppGpp synthesis defect were analyzed and it was established that bacteria could accumulate in tumors after intravenous administration to various types of tumor-bearing mice. Solid tumors were especially sensitive with extensive hemorrhagic areas. Most bacteria have the ability to attack and colonize cancer cells, and in best cases, this leads to the treatment of cancer completely. The recent studies demonstrated that the microbiome within the human body targeted the tumor cells because of decreased immune activity in the necrotic cores of tumor. Some bacteria can grow into tumors that are preferred for reproduction by consuming food and oxygen, causing cancer cells to starve and suffocate. This phenomenon opened the doors to the possibility of using nonpathogenic bacteria to deliver drugs into the tumor [47].

Several bacterial strains/species have been discovered to possess inherent oncolytic potentials to invade and colonize solid tumors in vivo. Anti-cancer drugs cause the induction of biofilm formation during cancer treatment, which results in metastasis distraction. In addition to disrupting metastasis, the biofilm can modify the metabolism of the tumor, such as affecting the regulator of cell proliferation of colon cancer. Also, the bacterial macromolecules necessary for biofilm formation such as proteins and DNA coat cancer cells to block metastasis. For example, polysaccharides released by Streptococcus agalactiae inhibit adhesion of cancer cells to endothelial cells, an essential step in cancer metastasis. Furthermore, demonstrates the potential application of iron oxide nanowires from a biofilm waste produced by bacteria
(Mariprofundus ferroxydans) as a new multifunctional drug carrier for cancer therapy and cancer hyperthymia. Bacterial biofilm has the potential for a new method of anti-cancer therapy, especially for metastases, but this issue requires further examination in consequence the lack of available data [48].

However, the variability in the composition of the extracellular polymeric substance (EPS) matrix and the interactions among the various components add new levels of complexity and provide challenges for the development of EPS-targeting therapeutics. Treating biofilm infections requires combination therapies or those that target more than one component of the complex biofilm microenvironment, similar to tumouregenesis. Many biofilm management strategies being devised in the clinic and used by surgeons, are largely based on an approach from cancer treatment: early and aggressive irrigation and debridement for physically removal and local delivery of high and sustained antimicrobial chemotherapy. Thus, eliminating existing biofilms may require simultaneous degradation of the protective EPS matrix, and targeting and killing both resident microorganisms and dispersed cells. Thus, the biological effects can be tuned to specifically target the biofilm microenvironment, degrade the matrix and kill resident bacteria, thereby eradicating the pathogenic niche with precision and minimal cytotoxicity to surrounding tissues [49].

A novel approach is bacteriotherapy, either used alone, or in combination with conventional methods, has shown a positive effect on regression of tumors and inhibition of metastasis. Bacteria-assisted tumor-targeted therapy used as therapeutic/gene/drug delivery vehicles has great promise in the treatment of tumors. Tumor regression was observed with applying bacteriotherapy solely or along with standard methods in experimental researches. The most common bacteria used in this field are the genera Salmonella, Clostridium, Bifidobacterium, Lactobacillus, Escherichia, Pseudomonas, Caulobacter, Listeria, Proteus, and Streptococcus. The use of three species of bacteria, Clostridia, Bifidobacteria, and Salmonellae as vectors for delivering or expressing tumor suppressor genes, anti-angiogenic genes, suicide genes, or tumor-associated antigens has been tested in animal models bearing various tumors. One of the fundamental explanations for the lack of efficacy of radiotherapy in some solid tumors is the presence of hypoxic (i.e. poorly vascularized) zones that are resistant to radiation. It was found that bacteria under hypoxic conditions produced antibodies, which bind with factor $1 \alpha$ enabled to affect the process of transcription of tumor cells. However, this limitation could be an advantage for other approaches, for example, the use of facultative or obligate anaerobic bacteria [50].

\section{CONCLUSION}


The bacterial influence on the tumor can produce dual effect as two sides of a coin. Understanding the intricacy and variability of biofilm biology and tumor's composition highlight the approaches of new models chemotherapy. Stress conditions and heterogeneous microenvironment may produce a similar answer of biofilm and tumor that closely associated with cellular constituents and modulated immune response. These dynamic properties lead to increased therapeutic index or facilitate synergy of bacterial and cancer cells. Further studies should focus the structural microbial and tumoral microenvironment that can be exploited to design unexplored and selective drug delivery approaches. Microorganisms can be represented as biomarkers of increased cancer risk that evaluate the patient's prognosis and aim to combat the progression of tumors. Engineering tumor-targeting bacteria may reveal potential tailor-made therapies and develop of personalized treatments. The combination of approaches of bacteriotherapy with chemotherapy can help in defeating the tumor heterogeneity accompanied with malignancy, drug-resistance and metastasis. This review covered biofilm and tumor properties related by microenvironment with "unique conceptual similarities". Genetic instability, multicellular cooperation, metabolic context are important subjects for further study to enhance the understanding the complex effects on different types of cells in divers microenvironmental conditions.

\section{REFERENCES}

1. Vestby LK, Grønseth T, Simm R, Nesse LL. Bacterial Biofilm and its Role in the Pathogenesis of Disease. Antibiotics (Basel). 2020; 9(2):59. doi: 10.3390/ antibiotics9020059.

View at: Publisher Site: https://www.mdpi. com/2079-6382/9/2/59

PubMed: https://pubmed.ncbi.nlm.nih.gov/32028684/ PubMed Central: https://www.ncbi.nlm.nih.gov/pmc/ articles/PMC7167820/

2. Bjarnsholt T., Buhlin K., Dufrêne Y. F., Gomelsky M., Moroni A., Ramstedt M. [et al.] Biofilm formation what we can learn from recent developments. J Intern Med. 2018; 284(4): 332-45. doi:10.1111/joim. 12782. View at: Publisher Site: https://onlinelibrary.wiley.com/ doi/full/10.1111/joim.12782

PubMed: https://pubmed.ncbi.nlm.nih.gov/29856510/ PubMed Central: https://www.ncbi.nlm.nih.gov/pmc/ articles/PMC6927207/

3. Maali Y, Journo C, Mahieux R, Dutartre H. Microbial Biofilms: Human T-cell Leukemia Virus Type 1 First in Line for Viral Biofilm but Far Behind Bacterial Biofilms. Front Microbiol. 2020; 11:2041. doi: 10.3389/ fmicb.2020.02041.

View at: Publisher Site: https://www.frontiersin.org/ articles/10.3389/fmicb.2020.02041/full

PubMed: https://pubmed.ncbi.nlm.nih.gov/33042035/ PubMed Central: https://www.ncbi.nlm.nih.gov/pmc/ articles/PMC7523422/
4. Berlanga M, Guerrero R. Living together in biofilms: the microbial cell factory and its biotechnological implications. Microb Cell Fact. 2016; 15(1):165. doi: 10.1186/s12934-016-0569-5.

View at: Publisher Site: https://microbialcellfactories.biomedcentral.com/articles/10.1186/ s12934-016-0569-5

PubMed: https://pubmed.ncbi.nlm.nih.gov/27716327/ PubMed Central: https://www.ncbi.nlm.nih.gov/pmc/ articles/PMC5045575/

5. Alav I, Sutton JM, Rahman KM. Role of bacterial efflux pumps in biofilm formation. J Antimicrob Chemother. 2018; 73(8):2003-2020. doi: 10.1093/jac/dky042.

View at: Publisher Site: https://academic.oup.com/jac/ article/73/8/2003/4913710

PubMed: https://pubmed.ncbi.nlm.nih.gov/29506149/

6. Benoit DS, Koo H. Targeted, triggered drug delivery to tumor and biofilm microenvironments. Nanomedicine (Lond). 2016; 11(8):873-9. doi: 10.2217/ nnm-2016-0014.

View at: Publisher Site: https://www.futuremedicine. com/doi/full/10.2217/nnm-2016-0014

PubMed: https://pubmed.ncbi.nlm.nih.gov/26987892/ Europe PMC: https://europepmc.org/article/ $\mathrm{med} / 26987892$

7. Domingue JC, Drewes JL, Merlo CA, Housseau F, Sears CL. Host responses to mucosal biofilms in the lung and gut. Mucosal Immunol. 2020; 13(3):413-22. doi: 10.1038/s41385-020-0270-1.

View at: Publisher Site: https://www.nature.com/ articles/s41385-020-0270-1

PubMed: https://pubmed.ncbi.nlm.nih.gov/32112046/ Scopus: https://jhu.pure.elsevier.com/en/publications/ host-responses-to-mucosal-biofilms-in-the-lung-and-gut

8. Sadiq FA, Flint S, Li Y, Ou K, Yuan L, He GQ. Phenotypic and genetic heterogeneity within biofilms with particular emphasis on persistence and antimicrobial tolerance. Future Microbiol. 2017; 12:1087-107. doi: 10.2217/fmb-2017-0042.

View at: Publisher Site: https://www.futuremedicine. com/doi/10.2217/fmb-2017-0042

PubMed: https://pubmed.ncbi.nlm.nih.gov/28783379/

Europe PMC: https://europepmc.org/article/ $\operatorname{med} / 28783379$

9. Yan J, Bassler BL. Surviving as a Community: Antibiotic Tolerance and Persistence in Bacterial Biofilms. Cell Host Microbe. 2019; 26(1):15-21. doi: 10.1016/j. chom.2019.06.002.

View at: Publisher Site: https:/www.cell.com/cellhost-microbe/fulltext/S1931-3128(19)30291-4? returnURL $=$ https $\% 3 \mathrm{~A} \% 2 \mathrm{~F} \% 2$ Flinkinghub.elsevier.com $\%$ 2Fretrieve\%2Fpii\%2FS1931312819302914\%3Fshowall $\% 3$ Dtrue

PubMed: https://pubmed.ncbi.nlm.nih.gov/31295420/ PubMed Central: https://www.ncbi.nlm.nih.gov/pmc/ articles/PMC6629468/

Scopus: https:/www.sciencedirect.com/science/article/ pii/S1931312819302914 
10. Windels EM, Michiels JE, Van den Bergh B, Fauvart M, Michiels J. Antibiotics: Combatting Tolerance To Stop Resistance. mBio. 2019; 10(5):e02095-19. doi: 10.1128/mBio.02095-19.

View at: Publisher Site: https://mbio.asm.org/ content/10/5/e02095-19

PubMed: https://pubmed.ncbi.nlm.nih.gov/31506315/ PubMed Central: https://www.ncbi.nlm.nih.gov/pmc/ articles/PMC6737247/

11. Endo H, Inoue M. Dormancy in cancer. Cancer Sci. 2019; 110(2):474-80. doi: 10.1111/cas.13917.

View at: Publisher Site: https://onlinelibrary.wiley.com/ doi/full/10.1111/cas.13917

PubMed: https://pubmed.ncbi.nlm.nih.gov/30575231/

PubMed Central: https://www.ncbi.nlm.nih.gov/pmc/ articles/PMC6361606/

12. Magana M, Sereti C, Ioannidis A, Mitchell CA, Ball AR, Magiorkinis E, Chatzipanagiotou S, Hamblin MR, Hadjifrangiskou M, Tegos GP. Options and Limitations in Clinical Investigation of Bacterial Biofilms. Clin Microbiol Rev. 2018; 31(3):e00084-16. doi: 10.1128/ CMR.00084-16.

View at: Publisher Site: https://cmr.asm.org/ content/31/3/e00084-16

PubMed: https://pubmed.ncbi.nlm.nih.gov/29618576/

PubMed Central: https://www.ncbi.nlm.nih.gov/pmc/ articles/PMC6056845/

13. Rizzato C, Torres J, Kasamatsu E, Camorlinga-Ponce M, Bravo MM, Canzian F, Kato I. Potential Role of Biofilm Formation in the Development of Digestive Tract Cancer With Special Reference to Helicobacter pylori Infection. Front Microbiol. 2019; 10:846. doi: 10.3389/fmicb.2019.00846.

View at: Publisher Site: https://www.frontiersin.org/ articles/10.3389/fmicb.2019.00846/full

PubMed: https://pubmed.ncbi.nlm.nih.gov/31110496/

PubMed Central: https://www.ncbi.nlm.nih.gov/pmc/ articles/PMC6501431/

14. Bisht K, Wakeman CA. Discovery and Therapeutic Targeting of Differentiated Biofilm Subpopulations. Front Microbiol. 2019; 10:1908. doi: 10.3389/ fmicb.2019.01908.

View at: Publisher Site: https://www.frontiersin.org/ articles/10.3389/fmicb.2019.01908/full

PubMed: https://pubmed.ncbi.nlm.nih.gov/31507548/

PubMed Central: https://www.ncbi.nlm.nih.gov/pmc/ articles/PMC6718512/

15. Kayser J, Schreck CF, Gralka M, Fusco D, Hallatschek O. Collective motion conceals fitness differences in crowded cellular populations. Nat Ecol Evol. 2018; 3(1):125-34. doi: 10.1038/s41559-018-0734-9.

View at: Publisher Site: https://www.nature.com/ articles/s41559-018-0734-9

PubMed: https://pubmed.ncbi.nlm.nih.gov/30510177/

PubMed Central: https://www.ncbi.nlm.nih.gov/pmc/ articles/PMC6309230/

16. Gough A, Stern AM, Maier J, Lezon T, Shun TY, Chennubhotla C, Schurdak ME, Haney SA, Taylor DL. Bi- ologically Relevant Heterogeneity: Metrics and Practical Insights. SLAS Discov. 2017; 22(3):213-37. doi: $10.1177 / 2472555216682725$.

View at: Publisher Site: https://journals.sagepub.com/ doi/10.1177/2472555216682725

PubMed: https://pubmed.ncbi.nlm.nih.gov/28231035/ PubMed Central: https://www.ncbi.nlm.nih.gov/pmc/ articles/PMC5464733/

17. Hall CW, Mah TF. Molecular mechanisms of biofilm-based antibiotic resistance and tolerance in pathogenic bacteria. FEMS Microbiol Rev. 2017; 41(3):276-301. doi: 10.1093/ femsre/fux010.

View at: Publisher Site: https://academic.oup.com/femsre/ article/41/3/276/3089981

PubMed: https://pubmed.ncbi.nlm.nih.gov/28369412/

Europe PMC: https://europepmc.org/article/med/28369412

18. Mingzhou Guo, Yaojun Peng, Aiai Gao, Chen Du, James G. Herman. Epigenetic heterogeneity in cancer. Biomark Res. 2019; 7: 23. doi: 10.1186/ s40364-019-0174-y.

View at: Publisher Site: https://biomarkerres.biomedcentral.com/articles/10.1186/s40364-019-0174-y

PubMed: https://pubmed.ncbi.nlm.nih.gov/31695915/ PubMed Central: https://www.ncbi.nlm.nih.gov/pmc/ articles/PMC6824025/

19. Stanta G, Bonin S. Overview on Clinical Relevance of Intra-Tumor Heterogeneity. Front Med (Lausanne). 2018; 5:85. doi: 10.3389/fmed.2018.00085.

View at: Publisher Site: https://www.frontiersin.org/ articles/10.3389/fmed.2018.00085/full

PubMed: https://pubmed.ncbi.nlm.nih.gov/29682505/ PubMed Central: https://www.ncbi.nlm.nih.gov/pmc/ articles/PMC5897590/

20. Zhang Q, Lou Y, Bai XL, Liang TB. Intratumoral heterogeneity of hepatocellular carcinoma: From single-cell to population-based studies. World J Gastroenterol. 2020; 26(26):3720-36. doi: 10.3748/wjg.v26.i26.3720.

View at: Publisher Site: https://www.wjgnet.com/10079327/full/v26/i26/3720.htm

PubMed: https://pubmed.ncbi.nlm.nih.gov/32774053/ PubMed Central: https://www.ncbi.nlm.nih.gov/pmc/ articles/PMC7383842/

21. Rübben A, Araujo A. Cancer heterogeneity: converting a limitation into a source of biologic information. J Transl Med. 2017; 15(1):190. doi: 10.1186/ s12967-017-1290-9.

View at: Publisher Site: https://translational-medicine. biomedcentral.com/articles/10.1186/s12967-017-1290-9

22. Stanta G, Bonin S. A Practical Approach to Tumor Heterogeneity in Clinical Research and Diagnostics. Pathobiology. 2018; 85(1-2):7-17. doi: 10.1159/000477813. View at: Publisher Site: https://www.karger.com/ Article/FullText/477813

PubMed: https://pubmed.ncbi.nlm.nih.gov/28750401/ 23. Gay L, Baker AM, Graham TA. Tumour Cell Heterogeneity. F1000Res. 2016; 5:F1000 Faculty Rev-238. doi: 10.12688/f1000research.7210.1.

View at: Publisher Site: https://f1000research.com/ 
articles $/ 5-238$

PubMed: https://pubmed.ncbi.nlm.nih.gov/26973786/ PubMed Central: https://www.ncbi.nlm.nih.gov/pmc/ articles/PMC4776671/

24. Han Y, Jo H, Cho JH, Dhanasekaran DN, Song YS. Resveratrol as a Tumor-Suppressive Nutraceutical Modulating Tumor Microenvironment and Malignant Behaviors of Cancer. Int J Mol Sci. 2019; 20(4): 925. doi: 10.3390/ijms20040925.

View at: Publisher Site: https://www.mdpi. com/1422-0067/20/4/925

PubMed: https://pubmed.ncbi.nlm.nih.gov/30791624/ PubMed Central: https://www.ncbi.nlm.nih.gov/pmc/ articles/PMC6412705/

25. Dharmaraja AT. Role of Reactive Oxygen Species (ROS) in Therapeutics and Drug Resistance in Cancer and Bacteria. J Med Chem. 2017; 60(8):3221-40. doi: 10.1021/acs.jmedchem.6b01243.

View at: Publisher Site: https://pubs.acs.org/doi/10.1021/ acs.jmedchem.6b01243

PubMed: https://pubmed.ncbi.nlm.nih.gov/28135088/

Europe PMC: https://europepmc.org/article/med/28135088

26. Greten FR, Grivennikov SI. Inflammation and Cancer: Triggers, Mechanisms, and Consequences. Immunity. 2019; 51(1):27-41. doi: 10.1016/j.immuni.2019.06.025. View at: Publisher Site: https://www.cell.com/immunity/fulltext/S1074-7613(19)30295-X?_returnURL $=$ https $\% 3 \mathrm{~A} \% 2 \mathrm{~F} \% 2$ Flinkinghub.elsevier.com $\%$ 2Fretrieve\%2Fpii\%2FS107476131930295X\%3Fshowall $\% 3$ Dtrue

PubMed: https://pubmed.ncbi.nlm.nih.gov/31315034/ PubMed Central: https://www.ncbi.nlm.nih.gov/pmc/ articles/PMC6831096/

Scopus: https://www.sciencedirect.com/science/article/ pii/S107476131930295X

Europe PMC: https://europepmc.org/article/ $\mathrm{med} / 31315034$

27. Yang L., Lin PC. Mechanisms that drive inflammatory tumor microenvironment, tumor heterogeneity, and metastatic progression. Semin Cancer Biol. 2017; 47:185-95. doi: 10.1016/j.semcancer.2017.08.001.

View at: Publisher Site: Scopus: https://www. sciencedirect.com/science/article/abs/pii/ S1044579X17302055?via\%3Dihub

PubMed: https://pubmed.ncbi.nlm.nih.gov/28782608/ PubMed Central: https://www.ncbi.nlm.nih.gov/pmc/ articles/PMC5698110/

Europe PMC: https://europepmc.org/article/ $\mathrm{med} / 28782608$

28. Armstrong H, Bording-Jorgensen M, Dijk S, Wine E. The Complex Interplay between Chronic Inflammation, the Microbiome, and Cancer: Understanding Disease Progression and What We Can Do to Prevent It. Cancers (Basel). 2018; 10(3):83. doi: 10.3390/cancers10030083. View at: Publisher Site: https://www.mdpi. com/2072-6694/10/3/83

PubMed: https://pubmed.ncbi.nlm.nih.gov/29558443/ PubMed Central: https://www.ncbi.nlm.nih.gov/pmc/
articles/PMC5876658/

29. Johnson CH, Spilker ME, Goetz L, Peterson SN, Siuzdak G. Metabolite and Microbiome Interplay in Cancer Immunotherapy. Cancer Res. 2016; 76(21):6146-52. doi: 10.1158/0008-5472.CAN-16-0309.

View at: Publisher Site: https://cancerres.aacrjournals. org/content/76/21/6146

PubMed: https://pubmed.ncbi.nlm.nih.gov/27729325/

PubMed Central: https://www.ncbi.nlm.nih.gov/pmc/ articles/PMC5093024/

30. van Elsland D, Neefjes J. Bacterial infections and cancer. EMBO Rep. 2018; 19(11):e46632. doi: 10.15252/ embr.201846632.

View at: Publisher Site: https://www.embopress.org/ doi/full/10.15252/embr.201846632

PubMed: https:/pubmed.ncbi.nlm.nih.gov/30348892/

PubMed Central: https://www.ncbi.nlm.nih.gov/pmc/ articles/PMC6216254/

31. Abd-El-Raouf R, Ouf SA, Gabr MM, Zakaria MM, El-Yasergy KF, Ali-El-Dein B. Escherichia coli foster bladder cancer cell line progression via epithelial mesenchymal transition, stemness and metabolic reprogramming. Sci Rep. 2020 Oct 22; 10(1):18024. doi: 10.1038/s41598-020-74390-5.

View at: Publisher Site: https://www.nature.com/ articles/s41598-020-74390-5

32. Li S, Peppelenbosch MP, Smits R. Bacterial biofilms as a potential contributor to mucinous colorectal cancer formation. Biochim Biophys Acta Rev Cancer. 2019; 1872(1):74-9. doi: 10.1016/j.bbcan.2019.05.009.

View at: Publisher Site: Scopus: https:// www.sciencedirect.com/science/article/pii/ S0304419X19300320?via\%3Dihub

PubMed: https://pubmed.ncbi.nlm.nih.gov/31201828/

33. Tomkovich S, Jobin C. Microbial networking in cancer: when two toxins collide. Br J Cancer. 2018; 118(11):1407-9. doi: 10.1038/s41416-018-0101-2.

View at: Publisher Site: https://www.nature.com/ articles/s41416-018-0101-2

PubMed: https://pubmed.ncbi.nlm.nih.gov/29773837/ PubMed Central: https://www.ncbi.nlm.nih.gov/pmc/ articles/PMC5988818/

34. Lang M, Baumgartner M, Rożalska A, Frick A, Riva A, Jarek M, Berry D, Gasche C. Crypt residing bacteria and proximal colonic carcinogenesis in a mouse model of Lynch syndrome. Int J Cancer. 2020; 147(8):231626. doi: 10.1002/ijc.33028.

View at: Publisher Site: https://onlinelibrary.wiley.com/ doi/full/10.1002/ijc.33028

35. Brennan CA, Garrett WS. Fusobacterium nucleatum - symbiont, opportunist and oncobacterium. Nat Rev Microbiol. 2019 Mar; 17(3):156-66. doi: 10.1038/ s41579-018-0129-6.

View at: Publisher Site: https://www.nature.com/ articles/s41579-018-0129-6

PubMed: https:/pubmed.ncbi.nlm.nih.gov/30546113/ PubMed Central: https://www.ncbi.nlm.nih.gov/pmc/ articles/PMC6589823/ 
36. Tomkovich S, Gharaibeh RZ, Dejea CM, Pope JL, Jiang J, Winglee K, Gauthier J, Newsome RC, Yang Y, Fodor AA, Schmittgen TD, Sears CL, Jobin C. Human Colon Mucosal Biofilms and Murine Host Communicate via Altered mRNA and microRNA Expression during Cancer. mSystems. 2020; 5(1):e00451-19. doi: 10.1128/mSystems.00451-19.

View at: Publisher Site: https://msystems.asm.org/ content/5/1/e00451-19/article-info

URL: https://www.meta.org/papers/human-colon-mucosal-biofilms-and-murine-host/31937674

37. Longhi G, van Sinderen D, Ventura M, Turroni F. Microbiota and Cancer: The Emerging Beneficial Role of Bifidobacteria in Cancer Immunotherapy. Front Microbiol. 2020; 11:575072. doi: 10.3389/ fmicb.2020.575072.

View at: Publisher Site: https://www.frontiersin.org/ articles/10.3389/fmicb.2020.575072/full

PubMed: https://pubmed.ncbi.nlm.nih.gov/33013813/ PubMed Central: https://www.ncbi.nlm.nih.gov/pmc/ articles/PMC7507897/

38. Lopetuso LR, Severgnini M, Pecere S, Ponziani FR, Boskoski I, Larghi A, Quaranta G, Masucci L, Ianiro G, Camboni T, Gasbarrini A, Costamagna G, Consolandi C, Cammarota G. Esophageal microbiome signature in patients with Barrett's esophagus and esophageal adenocarcinoma. PLoS One. 2020; 15(5):e0231789. doi: 10.1371/journal.pone.0231789.

View at: Publisher Site: https://journals.plos.org/ plosone/article?id=10.1371/journal.pone.0231789

PubMed: https://pubmed.ncbi.nlm.nih.gov/32369505/

PubMed Central: https://www.ncbi.nlm.nih.gov/pmc/ articles/PMC7199943/

39. Elsalem L, Jum'ah AA, Alfaqih MA, Aloudat O. The Bacterial Microbiota of Gastrointestinal Cancers: Role in Cancer Pathogenesis and Therapeutic Perspectives. Clin Exp Gastroenterol. 2020; 13:151-85. doi: 10.2147/CEG.S243337.

View at: Publisher Site: https:/www.dovepress.com/ the-bacterial-microbiota-of-gastrointestinal-cancers-role-in-cancer-pa-peer-reviewed-article-CEG PubMed: https://pubmed.ncbi.nlm.nih.gov/32440192/ PubMed Central: https://www.ncbi.nlm.nih.gov/pmc/ articles/PMC7211962/

40. McNitt DH, Choi SJ, Allen JL, Hames RA, Weed SA, Van De Water L, Berisio R, Lukomski S. Adaptation of the group A Streptococcus adhesin Scl1 to bind fibronectin type III repeats within wound-associated extracellular matrix: implications for cancer therapy. Mol Microbiol. 2019; 112(3):800-19. doi: 10.1111/ mmi.14317.

View at: Publisher Site: https://onlinelibrary.wiley.com/ doi/full/10.1111/mmi.14317

41. Saputo S, Faustoferri RC, Quivey RG Jr. A Drug Repositioning Approach Reveals that Streptococcus mutans Is Susceptible to a Diverse Range of Established Antimicrobials and Nonantibiotics. Antimicrob Agents Chemother. 2017; 62(1):e01674-17. doi:
10.1128/AAC.01674-17.

View at: Publisher Site: https://aac.asm.org/ content/62/1/e01674-17

42. Teteneva NA, Mart'yanov SV, Esteban-López M, Kahnt J, Glatter T, Netrusov AI, Plakunov VK, Sourjik V. Multiple Drug-Induced Stress Responses Inhibit Formation of Escherichia coli Biofilms. Appl Environ Microbiol. 2020; 86(21):e01113-20. doi: 10.1128/ AEM.01113-20.

View at: Publisher Site: https://aem.asm.org/ content/86/21/e01113-20

PubMed: https://pubmed.ncbi.nlm.nih.gov/32826218/ PubMed Central: https://www.ncbi.nlm.nih.gov/pmc/ articles/PMC7580552/

43. Yaghoubi A, Khazaei M, Hasanian SM, Avan A, Cho WC, Soleimanpour S. Bacteriotherapy in Breast Cancer. Int J Mol Sci. 2019; 20(23):5880. doi: 10.3390/ ijms20235880.

View at: Publisher Site: https://www.mdpi. com/1422-0067/20/23/5880

PubMed: https://pubmed.ncbi.nlm.nih.gov/31771178/

PubMed Central: https://www.ncbi.nlm.nih.gov/pmc/ articles/PMC6928964/

44. Duong MT, Qin Y, You SH, Min JJ. Bacteria-cancer interactions: bacteria-based cancer therapy. Exp Mol Med. 2019; 51(12):1-15. doi: 10.1038/ s12276-019-0297-0.

View at: Publisher Site: https://www.nature.com/ articles/s12276-019-0297-0

PubMed: https://pubmed.ncbi.nlm.nih.gov/31827064/ PubMed Central: https://www.ncbi.nlm.nih.gov/pmc/ articles/PMC6906302/

45. Zhou S, Gravekamp C, Bermudes D, Liu K. Tumour-targeting bacteria engineered to fight cancer. Nat Rev Cancer. 2018; 18(12):727-43. doi: 10.1038/ s41568-018-0070-z.

View at: Publisher Site: https://www.nature.com/ articles/s41568-018-0070-z

PubMed: https://pubmed.ncbi.nlm.nih.gov/30405213/ PubMed Central: https:/www.ncbi.nlm.nih.gov/pmc/ articles/PMC6902869/

46. Sawant SS, Patil SM, Gupta V, Kunda NK. Microbes as Medicines: Harnessing the Power of Bacteria in Advancing Cancer Treatment. Int J Mol Sci. 2020; 21(20):7575. doi: 10.3390/ijms21207575.

View at: Publisher Site: https://www.mdpi. com/1422-0067/21/20/7575

PubMed: https://pubmed.ncbi.nlm.nih.gov/33066447/ PubMed Central: https://www.ncbi.nlm.nih.gov/pmc/ articles/PMC7589870/

47. Al-Hilu SA, Al-Shujairi WH. Dual Role of Bacteria in Carcinoma: Stimulation and Inhibition. Int J Microbiol. 2020; 2020:4639761. doi: 10.1155/2020/4639761. View at: Publisher Site: https://www.hindawi.com/ journals/ijmicro/2020/4639761/

PubMed: https://pubmed.ncbi.nlm.nih.gov/32908523/ PubMed Central: https://www.ncbi.nlm.nih.gov/pmc/ articles/PMC7463420/ 
48. Song S, Vuai MS, Zhong M. The role of bacteria in cancer therapy - enemies in the past, but allies at present. Infect Agent Cancer. 2018; 13:9. doi: 10.1186/ s13027-018-0180-y.

View at: Publisher Site: https://infectagentscancer.biomedcentral.com/articles/10.1186/ s13027-018-0180-y

PubMed: https://pubmed.ncbi.nlm.nih.gov/29568324/

PubMed Central: https://www.ncbi.nlm.nih.gov/pmc/ articles/PMC5856380/

49. Koo H, Allan RN, Howlin RP, Stoodley P, Hall-Stoodley L. Targeting microbial biofilms: current and prospective therapeutic strategies. Nat Rev Microbiol. 2017; 15(12):740-55. doi: 10.1038/nrmicro.2017.99.

View at: Publisher Site: https://www.nature.com/ articles/nrmicro.2017.99

PubMed: https://pubmed.ncbi.nlm.nih.gov/28944770/
PubMed Central: https://www.ncbi.nlm.nih.gov/pmc/ articles/PMC5685531/

50. Sedighi M, Zahedi Bialvaei A, Hamblin MR, Ohadi E, Asadi A, Halajzadeh M, Lohrasbi V, Mohammadzadeh N, Amiriani T, Krutova M, Amini A, Kouhsari E. Therapeutic bacteria to combat cancer; current advances, challenges, and opportunities. Cancer Med. 2019; 8(6):3167-81. doi: 10.1002/cam4.2148.

View at: Publisher Site: https://onlinelibrary.wiley.com/ doi/full/10.1002/cam4.2148

PubMed: https://pubmed.ncbi.nlm.nih.gov/30950210/ PubMed Central: https://www.ncbi.nlm.nih.gov/pmc/ articles/PMC6558487/

\title{
БІОПЛІВКА ТА ПУХЛИНА: ІНТЕРПРЕТАЦІЯ ВЗАСМОДІЇ ТА СТРАТЕГІї ЛІКУВАННЯ. ОГЛЯД
}

\author{
Іваненко Н.О. \\ Донецький національний медичний університет, Кропивницький, Украӥна \\ natalimarkowskaj@gmail.com
}

Актуальність. Лікування твердих пухлин і інфекцій, викликаних біоплівкою, стикається із загальною проблемою: ліки часто не досягають і не вбивають ракові клітини та мікробні патогени через локальне гетерогенне середовище. Сучасні та перспективні протипухлинні та антибактеріальні агенти стикаються зі значними проблемами щодо цілі та підтримки активності у мікросередовищі, де виживають ракові клітини та мікробні патогени, які викликають спалахи захворювання. Частка бактеріальних інфекцій у формуванні злоякісних пухлин буде збільшуватися в найближчі роки. Об'єднання підходів, таких як ROS модуляції у клітинах, пухлини, викликані за сприяння мікробного запалення, є стратегією, націленою на злоякісні пухлини та бактерії. Крім того, бактерії можуть скористатися перевагами кисневого голодування та дозвільних джерел вуглецю, тому мікросередовище пухлини стає потенційним притулком для бактерій. Примітно, що зв'язок між пухлиною та бактеріями тісно пов'язаний.

Мета. Проаналізувати подібність біоплівкового і пухлинного мікросередовища, що виробляється в умовах стресу та гетерогенного мікрооточення, для поєднання підходів бактеріотерапії з хіміотерапією, які можуть допомогти у зруйнуванні гетерогенності пухлини, пов'язаної зі злоякісними фенотипами раку, лікарською стійкістю і метастазами.

Метод. Аналітичний огляд літератури за ключовими словами з наукометричних баз даних PubMed, Wiley.

Результати. Бактерії ухиляються від антимікробного впливу в основному через персистенцію, або стійкість, яка може стати дрімаючою під час стаціонарної фази, і толерантність. Стійкі, толерантні до ліків та дрімаючі клітини раку в основному вивчалися в контексті пізнього рецидиву, особливо метастазів, в якому мікрооточення метастазів відіграє вирішальну роль. Біоплівки утворюються групами клітин в різних станах, що ростуть або не ростуть, метаболічно активних або неактивних в різних фракціях, в залежності від зрілості і хімічних градієнтів (О2 і поживних речовин) біоплівок, що виробляють фізіологічну гетерогенність. Гетерогенність в мікросередовищі пухлини може бути описана як неклітинний автономний драйвер різноманітності ракових клітин; в дуже різноманітному мікрооточенні різні клітинні фенотипи можуть пройти селекцію або ні в різних областях пухлини. Гіпоксія, окислювальний стрес і запалення були ідентифіковані як позитивні регулятори метастатичного потенціалу, лікарської стійкості і онкогенних властивостей злоякісних пухлин. Так само кишкова паличка і небезпечні для життя інфекційні патогени, такі як золотистий стафілокок і мікобактерії туберкульозу, значно чутливі до змін внутрішньоклітинного окислювального середовища. Виникає альтернативна парадигма, яка полягає в тому, що багато видів раку можуть бути викликані комменсальною мікробіотою чи шляхом транслокації і приєднання мікробів до ракових клітин, або шляхом віддаленого вивільнення активних мікробних метаболітів при запаленні. Мікробні фактори, такі як F. nucleatum, B. fragilis та представники Enterobacteriaceae, можуть сприяти виникненню захворювання у пацієнтів зі спадковою формою колоректального раку; сімейним аденоматозним поліпозом. Ці результати можуть призвести до розробки нових біомаркерів та терапевтичних засобів для виявлення та лікування раку, асоційованого з біоплівкою. В даний час близько $20 \%$ новоутворень у всьому світі можна віднести до інфекцій, причому щорічно реєструється близько 1,2 мільйона випадків захворювання. Кілька протипухлинних препаратів, які проявляли активність проти S. mutans, включаючи тамоксифен, доксорубіцин і понатиніб, також мали активність проти інших грампозитивних бактерій. Перепрофілювання ліків, також відоме як репозиція, набрало обертів, головним чином, завдяки своїм перевагам перед відкриттям ліків de novo, включаючи зниження ризику для пацієнтів через раніше задокументовані клінічні випробування, зниження витрат на розробку ліків і більш швидкий перехід від випробувань до клініки. Хоча багато 
бактерій є канцерогенами і промоторами пухлин, деякі з них показали великий потенціал в лікуванні раку. Кілька видів бактерій продемонстрували вражаючу здатність проникати в тверді пухлини і колонізувати їх, що часто призводило до уповільнення зростання новоутворень і їх кліренсу. Різні штами Clostridia, Lactococcus, Bifidobacteria, Shigella, Vibrio, Listeria, Escherichia, та Salmonella були оцінені проти злоякісних пухлин на тваринних моделях.

Висновок. Рак - це багатофакторне захворювання, і використання бактерій для терапії раку, як імуностимулюючого агента або вектора для перенесення терапевтичного вантажу, є перспективним методом лікування. Тому світ звернувся до альтернативного рішення, яке полягає у використанні генно-інженерних мікроорганізмів. Використання живих бактерій, націлених на ракові клітини, є унікальним варіантом подолання цих проблем. Бактеріальна терапія, незалежно від того, чи використовується вона окремо або в поєднанні з хіміотерапією, дає позитивний ефект при лікуванні декількох станів раку.

Ключові слова: біоплівка, пухлина, гетерогенність, біомаркер, репозиція, бактеріотерапія.

\section{БИОПЛЁНКА И ОПУХОЛЬ: ИНТЕРПРЕТАЦИЯ ВЗАИМОДЕЙСТВИЯ И СТРАТЕГИИ ЛЕЧЕНИЯ. Обзор}

\section{Иваненко Н. А.}

Донеикий национальный медицинский университет, Кропивницикий,Украина

natalimarkowskaj@gmail.com

Актуальность. Лечение твёрдых опухолей и инфекций, вызванных биопленкой, сталкивается с общей проблемой: лекарства часто не достигают и не убивают раковые клетки и микробные патогены из-за гетерогенности местного микроокружения. Современные и перспективные противоопухолевые и антибактериальные агенты сталкиваются с серьёзными проблемами в отношении цели и поддержки активности в микроокружении, где раковые клетки и микробные патогены выживают и вызывают начало заболевания. Роль бактериальных инфекций в формировании рака будет увеличиваться в ближайшие годы. Объединение подходов, таких как ROS модуляция в клетках, опухоль со способствующим микробным воспалением, может стать стратегией нацеливания на рак и бактерии. Кроме того, бактерии могут воспользоваться преимуществами кислородного голодания и доступными источниками углерода, поэтому микросреда опухоли становится потенциальным убежищем для бактерий. Примечательно, что связь между раком и бактериями тесно переплетена.

Цель: проанализировать сходство биопленочной и опухолевой сред, вырабатываемой в условиях стресса и гетерогенного микроокружения, для сочетания подходов бактериотерапии с химиотерапией, которые могут помочь в деструкции гетерогенности опухоли, связанной со злокачественными фенотипами рака, лекарственной устойчивостью и метастазами.

Метод. Аналитический обзор литературы по ключевым словам из наукометрических баз данных PubMed, Wiley.

Результаты. Бактерии уклоняются от антимикробного воздействия в основном из-за персистенции, или устойчивости, которая может стать дремлющей во время стационарной фазы, и толерантности. Стойкие, толерантные к лекарствам и дремлющие клетки рака в основном изучались в контексте позднего рецидива, в особенности метастазов, в котором микросреда метастазов играет решающую роль. Биопленки образуются группами клеток в различных состояниях, растущих или нерастущих, метаболически активных или неактивных в различных фракциях, в зависимости от зрелости и химических градиентов (O2 и питательных веществ) биопленок, производящих физиологическую гетерогенность. Гетерогенность в микроокружении рака может быть описана как неклеточный автономный драйвер разнообразия раковых клеток; в очень разнообразном микроокружении различные клеточные фенотипы могут пройти селекцию или нет в различных областях опухоли. Гипоксия, окислительный стресс и воспаление были идентифицированы как положительные регуляторы метастатического потенциала, лекарственной устойчивости и онкогенных свойств при раке. Точно так же кишечная палочка и опасные для жизни инфекционные патогены, такие как золотистый стафилококк и микобактерии туберкулеза, значительно чувствительны к изменениям внутриклеточной окислительной среды. Возникающая альтернативная парадигма заключается в том, что многие виды рака могут быть вызваны комменсальной микробиотой или путем транслокации и присоединения микробов к раковым клеткам, либо путем отдаленного высвобождения активирующих воспаление микробных метаболитов. Микробные факторы, такие как F. nucleatum, B. fragilis и представители Enterobacteriaceae, могут способствовать возникновению заболевания у пациентов с наследственной формой колоректального рака; семейным аденоматозным полипозом. Эти результаты могут привести к разработке новых биомаркеров и терапевтических средств для выявления и лечения рака, ассоциированного с биопленкой. В настоящее время около 20 \% новообразований во всем мире можно отнести к инфекциям, причем ежегодно регистрируется около 1,2 миллиона случаев заболевания. Несколько противоопухолевых препаратов, которые проявляли активность против S. mutans, включая тамоксифен, доксорубицин и понатиниб, также обладали активностью против других грамположительных бактерий. Перепрофилирование лекарств, также известное как репозиция, набрало обороты, главным образом, благодаря своим преимуществам перед открытием лекарств de novo, включая снижение риска для пациентов из-за ранее задокументированных клинических испытаний, снижение затрат на разработку лекарств и более быстрый переход от испытаний к клинике. Хотя многие бактерии являются канцерогенами и промоторами опухолей, некоторые из них показали большой потенциал в лечении рака. Несколько видов бактерий продемонстрировали впечатляющую способность проникать в твердые опухоли и колонизировать их, что часто приводило к замедлению роста новообразований и их клиренсу. Различные штаммы Clostridia, Lactococcus, Bifidobacteria, Shigella, Vibrio, Listeria, Escherichia, и Salmonella были оценены против рака на животных моделях.

Вывод. Рак является многофакторным заболеванием, и использование бактерий для терапии рака в качестве иммуностимулирующего агента или вектора для переноса терапевтического груза является перспективным методом лечения. Поэтому мир 
Ivanenko N.

обратился к альтернативному решению, которое заключается в использовании генно-инженерных микроорганизмов. Использование живых бактерий, нацеленных на раковые клетки, является уникальным вариантом преодоления этих проблем. Бактериальная терапия, независимо от того, используется ли она отдельно или в сочетании с химиотерапией, дает положительный эффект при лечении нескольких состояний рака.

Ключевые слова: биопленка, опухоль, гетерогенность, биомаркер, репозиция, бактериотерапия. 